\title{
PENGGUNAAN LEMBAR KERJA SISWA DENGAN METODE PEMBELAJARAN PENEMUAN TERBIMBING UNTUK MENINGKATKAN MOTIVASI BELAJAR SISWA KELAS VIII SMP DHARMA KARYA UT
}

\author{
Hastri Rosiyanti $^{1)^{*}}$, Ghufron Kamil ${ }^{2)}$ \\ ${ }^{1)}$ Prodi Pendidikan Matematika, FIP, Universitas Muhammadiyah Jakarta \\ ${ }^{2)}$ SMP Dharma Karya UT Pondok Cabe \\ *hastrirosiyanti@gmail.com
}

\begin{abstract}
Abstrak
Penelitian tindakan kelas ini didasari oleh rendahnya motivasi belajar siswa SMP Kelas VIII1 Dharma Karya UT pada mata pelajaran matematika, yaitu sebagian besar indikator motivasi belajar tidak mencapai 75\%. Peneliti melakukan penelitian tindakan kelas guna meningkatkan motivasi belajar siswa dengan menggunakan metode pembelajaran penemuan terbimbing berbantuan lembar kerja siswa. Penggunaan metode pembelajaran penemuan terbimbing berbantuan lembar kerja siswa dilakukan pada proses pembelajaran di kelas. Desain penelitian ini mengacu pada proses pelaksanaan penelitian tindakan kelas model Kemmis\&Taggart. Waktu penelitian dilakukan selama 1 bulan dari observasi hingga dua siklus. Pada saat observasi, peneliti melakukan pre test dengan menyebarkan instrumen angket di hari pertama dan melakukan wawancara di hari kedua. Hasil pre-test menunjukkan bahwa $37,5 \%$ dari banyaknya indikator motivasi belajar siswa mencapai indikator keberhasilan dan hasil motivasi belajar 70,5\%. Selama dilakukannya penggunaan metode pembelajaran penemuan terbimbing berbantuan lembar kerja siswa, motivasi belajar siswa mengalami peningkatan. Pada siklus 1 menunjukkan bahwa 62,5\% dari banyaknya indikator motivasi belajar siswa mencapai indikator keberhasilan dan hasil motivasi belajar 81,5\%. Pada siklus 2 menunjukkan bahwa 100\% dari banyaknya indikator motivasi belajar siswa mencapai indikator keberhasilan dan hasil motivasi belajar 90,33\%.
\end{abstract}

Kata Kunci: Lembar Kerja Siswa, Metode Penemuan Terbimbing, Motivasi Belajar

\section{PENDAHULUAN}

Berdasarkan hasil observsi yang dilakukan selama dua kali, didapatkan data bahwa motivasi belajar siswa masih rendah. Pada hasil pengamatan, siswa lebih termotivasi mengerjakan soal yang mudah daripada soal yang sulit, hal ini didukung oleh hasil angket motivasi belajar siswa yaitu 47,9\% dengan kategori kurang. Siswa juga kurang termotivasi dalam berusaha mempertahankan pendapatnya saat diskusi. Tetapi dalam mengerjakan soal yang salah, siswa berusaha mencari jawaban dengan 
benar melalui bertanya oleh guru. Kendala waktu dan tidak kondusifnya di dalam kelas, guru tidak dapat menjawab semua pertanyaan dari siswanya.

Kondisi kelas pada proses pembelajaran tidak terkontrol, seperti siswa sering jalan-jalan di dalam kelas melihat dan berdiskusi dalam menyelesaikan masalah matematika bersama temannya. Peneliti menanggulangi hal tersebut dengan cara membuat kelompok, sehingga siswa dapat berdiskusi secara kelompok.

Selain hasil pengamatan dan hasil angket, peneliti juga memperoleh hasil wawancara dengan dua siswa, satu siswa yang memperoleh nilai terendah (A) dan satu siswa memperoleh nilai tertinggi (B) dalam mata pelajaran matematika. Hasil wawancara yang diperoleh dalam penelitian yaitu dari dua siswa menyatakan mata pelajaran matematika itu sulit. Siswa A menyatakan trauma dengan mata pelajaran matematika, karena pernah mendapatkan nilai jelek. Siswa B menyatakan mata pelajaran matematika sulit dipahami dibandingkan dengan mata pelajaran lainnya.

Pada saat wawancara dengan salah satu guru matematika di sekolah SMP Dharma Karya UT, guru menyampaikan bahwa siswa kelas VIII-1 kurang termotivasi dalam mempelajari materi pada mata pelajaran matematika. Semakin abstrak materi yang dihadapi semakin malas siswa mempelajari materi pada mata pelajaran matematika. Siswa lebih menyukai hal-hal yang lebih konkret, seperti kaitan materi yang sedang dipelajari dengan kehidupan sehari-hari.

Selain dari materi matematika, sumber belajar termasuk salah satu faktor yang menjadi motivasi belajar matematika siswa kurang. Siswa tidak pernah menggunakan sumber belajar LKS di sekolah, Dukungan sumber belajar di kelas kurang diperhatikan.

Berdasarkan latar belakang masalah yang telah diuraikan, maka peneliti perlu mendesain Lembar Kerja Siswa (LKS) berbasis metode pembelajaran penemuan terbimbing. LKS yang telah dirancang telah divalidasi oleh ahli pakar, sehingga dapat digunakan pada saat penelitian. Rumusan masalah pada penelitian ini untuk menunjukkan peningkatan motivasi belajar matematika siswa dalam menggunakan LKS berbasis metode pembelajaran penemuan terbimbing.

Matematika adalah suatu ilmu abstrak sehingga untuk memecahkan suatu masalah matematika harus mengubah ide abstrak menjadi suatu hal yang konkret, misalnya mengubahnya dengan gambar, symbol, atau dengan yang lainnya. Menurut Cornelius ada lima alasan perlunya belajar matemtika, yaitu (1) sarana berpikir yang jelas dan logis, (2) sarana untuk memecahkan masalah kehidupan sehari-hari, (3) sarana mengenal pola-pola hubungan dan generalisasi pengalaman, (4) sarana untuk mengembangkan kreativitas, dan (5) sarana untuk meningkatkan kesadaran terhadap perkembangan budaya (Fauziah, Hobri, dan Oktavianingtyas, 2016).

Matematika merupakan ilmu universal yang mendasari perkembangan teknologi modern, mempunyai peran penting dalam berbagai disiplin ilmu dan melatih daya pikir manusia. Menurut Badan Standar Nasional Pendidikan (BSNP) pelajaran matematika perlu diberikan kepada semua peserta didik mulai dari sekolah dasar untuk membekali peserta didik dengan kemampuan berpikir logis, analitis, sistematis, kritis, dan kreatif, serta kemampuan bekerjasama. Oleh sebab itu, maka sepatutnya diberikan perhatian yang 
lebih besar terhadap pembelajaran matematika untuk setiap jenjang pendidikan (Putri, 2016).

Menurut Turmudi, para siswa harus diberikan kesempatan, dorongan, dukungan untuk berbicara, menulis, membaca, dan mendengar dalam kelas matematika memiliki keuntungan ganda, yaitu mereka berkomunikasi untuk belajar matematika dan mereka berkomunikasi secara matematika karena matematika sering diberikan dalam komunikasi simbol, komunikasi tertulis, dan komunikasi lisan yang berisi gagasan matematika yang tidak selalu dikenal sebagai bagian penting dalam pendidikan matematika (Fadillah, 2015).

Menurut Bloom, belajar merupakan komponen ilmu pendidikan yang berkenaan dengan tujuan dan bahan acuan interaksi, baik yang bersifat eksplisit maupun implisit (Inda, 2017). Belajar juga dapat diartikan dengan suatu proses yang dilakukan oleh individu atau kelompok dengan sumber belajar yang bertujuan dalam memperoleh perubahan baik berupa sikap, pengetahuan ataupun keterampilan.

Motivasi adalah tenaga yang menggerakan dan mengarahkan aktivitas seseorang. Implikasi prinsip motivasi bagi pendidik tertampak pada perilaku-perilaku yang diantaranya ialah (1) memilih bahan ajar sesuai minat peserta didik, (2) menggunakan metode dan teknik mengajar yang disukai peserta didik, (3) Mengoreksi sesegera mungkin pekerjaan peserta didik dan sesegera mungkin memberitahukan hasilnya kepada peserta didik, (4) memberikan pujian verbal atau non-verbal terhadap peserta didik yang memberikan respon terhadap pertanyaan yang diberikan, (5) memberitahukan nilai guna dari pelajaran yang sedang dipelajari peserta didik (Sumar dan Razak, 2016:199).

Indikator motivasi belajar siswa yang digunakan adalah (1) Tekun dalam menghadapi tugas, (2) Ulet dalam menghadapi kesulitan, (3) Menunjukkan minat, (4) Senang bekerja mandiri, (5) Cepat bosan pada tugas- tugas rutin, (6) Dapat mempertahankan pendapatnya, (7) Tidak mudah melepas hal yang diyakini itu dan (8) Senang mencari dan memecahkan masalah soal-soal (Rosiyanti, 2016).

Prosedur penelitian lembar kerja siswa dengan menggunakan metode pembelajaran penemuan terbimbing adalah: (1) Membentuk 5 kelompok yang terdiri dari 3-4 siswa; (2) Peneliti menginstruksi dan memberikan kesempatan kepada siswa untuk mengidentifikasi masalah yang terdapat dalam LKS; (3) Peneliti membimbing siswa untuk menyelesaikan masalah yang tedapat di LKS; (4) Peneliti memberikan kesempatan kepada setiap kelompok untuk membuat satu soal yang baru mengenai materi yang sedang dipelajari; (5) Soal dan jawaban yang telah dibuat oleh setiap kelompok dipisahkan menjadi dua lembar; (6) lembar soal digulung lalu dilempar ke salah satu lawan kelompoknya; (7) setiap lawan kelompok mengerjakan soal dari lawan kelompok lainnya; (8) Hasil pengerjaan lawan kelompok dikembalikan ke kelompok pembuat soal; (9) kelompok pembuat soal mengoreksi dan memberi nilai dengan bimbingan peneliti; (10) menyimpulkan hasil pengerjaan siswa di kelas.

Berikut sekilas tampilan Lembar Kerja Siswa (LKS) berbasis metode pembelajarab penemuan terbimbing yang telah dikembangkan oleh peneliti. 


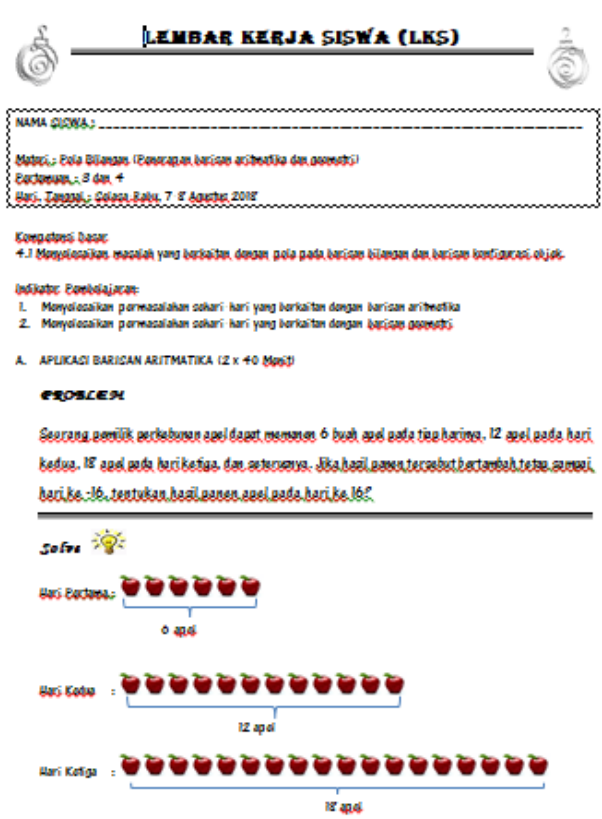

Gambar 1. Tampilan LKS

\section{METODE PENELITIAN}

Jenis penelitian yang digunakan adalah Penelitian Tindakan Kelas (PTK). Penelitian Tindakan Kelas ini merupakan penelitian tindakan yang dilakukan untuk meningkatkan motivasi belajar matematika siswa dengan menggunakan LKS melalui metode pembelajaran penemuan terbimbing pada materi Barisan aritmatika dan geometri. Desain penelitian ini menggunakan penelitian tindakan kelas model Kemmis\&Taggart dengan tahapan menyusun perencanaan tindakan (action plan), pelaksanaan tindakan (actuating), pengamatan (observing), dan refleksi (reflecting).

Penelitian ini dilaksanakan pada bulan Juli-September 2018 di SMP Dharma Karya UT yang beralamatkan Jalan Talas 2 No.30, Pondok Cabe Ilir, Pamulang, Pd. Cabe Ilir, Pamulang, Kota Tangerang Selatan, Banten 15418. Subjek penelitiannya adalah siswa-siswi kelas VIII-1. Setting penelitian ini menggunakan pembelajaran yang meliputi aktivitas siswa dalam pembelajaran matematika. Pelaksanaan penelitian dan pengambilan data diperoleh pada saat proses kegiatan pembelajaran berlangsung di dalam kelas.

Metode pengumpulan data yang digunakan dalam penelitian ini yaitu sebagai berikut: (1) Metode Observasi: Berkaitan dengan teknik pengumpulan data yang digunakan tersebut, maka instrumen pengumpulan data yang digunakan dalam metode observasi meliputi: catatan lapangan, pedoman wawancara, dan fotofoto. (2) Angket: Dalam penelitian ini angket yang digunakan adalah angket motivasi,belajar, sehingga 25 pernyataan yang disusun berdasarkan indikatorindikator motivasi belajar. Teknik angket dilaksanakan setiap akhir siklus dan digunakan untuk mencapai indikator keberhasilan.

Tabel 1. Pedoman Kualifikasi Hasil Skor Angket.

\begin{tabular}{cc}
\hline Skor & Kategori \\
\hline $75 \%<p \leq 100 \%$ & Tinggi \\
\hline $50 \%<p \leq 75 \%$ & Cukup \\
\hline $25 \%<p \leq 50 \%$ & Kurang \\
\hline $0 \% \leq p \leq 25 \%$ & Rendah \\
\hline Penelitian ini dinyatakan berhasil jika
\end{tabular}

hasil yang dicapai siswa (1) minimal $75 \%$ pada hasil motivasi belajar siswa dan (2) seluruh indikator motivasi belajar siswa mencapai minimal 75\%. Teknik analisis yang digunakan dalam menghitung data angket yaitu:

Keterangan:

$$
p=\frac{F}{N} \times 100 \%
$$

$p=$ angka persentasi

$F=$ skor keseluruhan yang diperoleh siswa

$N=$ jumlah subjek $\times$ skor maksimal 
Hastri Rosiyanti dan Ghufron Kamil: Penggunaan Lembar Kerja Siswa dengan Metode Pembelajaran Penemuan Terbimbing untuk Meningkatkan Motivasi Belajar Siswa Kelas VIII SMP Dharma Karya UT.

FIBONACCI : Jurnal Pendidikan Matematika dan Matematika. Vol. 4 (2), pp: 155-160.

\section{HASIL DAN PEMBAHASAN}

Penelitian ini dilaksanakan sebanyak 2 siklus dengan materi barisan aritmatika dan geometri. Kompetensi dasar pada siklus pertama yaitu menentukan pola barisan pada barisan bilangan dan konfigurasi objek dan kompetensi dasar pada siklus kedua yaitu menyelesaikan masalah yang berkaitan dengan pola pada barisan bilangan dan barisan konfigurasi objek. Hasil penelitian menunjukkan peningkatan motivasi belajar siswa pada setiap siklus.

Tabel 2. Perbandingan Motivasi Belajar

\begin{tabular}{ccccc}
\hline \multirow{2}{*}{ No } & Indikator & Pre-S & $\begin{array}{c}\text { Siklus } \\
\mathbf{1}\end{array}$ & $\begin{array}{c}\text { Siklus } \\
\mathbf{2}\end{array}$ \\
\cline { 2 - 5 } $\mathbf{\%}$ & $\mathbf{\%}$ & $\mathbf{\%}$ \\
\hline \multirow{2}{*}{1} & $\begin{array}{l}\text { Tekun dalam } \\
\text { menghadapi } \\
\text { kesulitan }\end{array}$ & 62 & 81,3 & 91,1 \\
\hline \multirow{2}{*}{2} & $\begin{array}{l}\text { Ulet dalam } \\
\text { menghadapi } \\
\text { kesulitan }\end{array}$ & 74,5 & 91,7 & 95,3 \\
\hline 3 & Menunjukkan & 64,6 & 82,8 & 91,1 \\
\hline
\end{tabular}

\section{SIMPULAN}

Hasil pre-test menunjukkan bahwa $37,5 \%$ dari banyaknya indikator motivasi belajar siswa mencapai indikator keberhasilan dan hasil motivasi belajar $70,5 \%$. Selama dilakukannya penggunaan metode pembelajaran penemuan terbimbing berbantuan lembar kerja siswa, motivasi belajar siswa mengalami peningkatan. Pada siklus 1 menunjukkan bahwa 62,5\% dari

\begin{tabular}{clccc}
\multirow{2}{*}{ No } & Indikator & Pre-S & $\begin{array}{c}\text { Siklus } \\
\mathbf{1}\end{array}$ & $\begin{array}{c}\text { Siklus } \\
\mathbf{2}\end{array}$ \\
\cline { 2 - 5 } & $\mathbf{\%}$ & $\mathbf{\%}$ & $\mathbf{\%}$ \\
\hline & minat & & \\
\hline 4 & $\begin{array}{l}\text { Senang bekerja } \\
\text { mandiri }\end{array}$ & 75 & 86,1 & 91 \\
\hline \multirow{2}{*}{5} & $\begin{array}{l}\text { Cepat bosan pada } \\
\text { tugas-tugas rutin }\end{array}$ & 49 & 72,9 & 84,4 \\
\hline \multirow{2}{*}{6} & $\begin{array}{l}\text { Dapat } \\
\text { mempertahankan } \\
\text { pendapatnya }\end{array}$ & 66 & 80,6 & 94,4 \\
\hline & $\begin{array}{l}\text { Tidak mudah } \\
\text { melepas hal yang } \\
\text { diyakini itu }\end{array}$ & 68,8 & 74 & 87,5 \\
\hline & $\begin{array}{l}\text { Senang mencari } \\
\text { dan memecahkan } \\
\text { masalah soal-soal }\end{array}$ & 61,1 & 73,6 & 82,6 \\
\hline Total & 65,83 & 81,5 & 90,3 \\
\hline \multicolumn{4}{l}{ Berdasarkan tabel 4.2, indikator yang }
\end{tabular}

memiliki persentasi yang paling rendah pada pre-siklus adalah indikator cepat bosan pada tugas-tugas rutin. Setelah menggunakan media LKS yang berbasis penemuan terbimbing, motivasi siswa lebih terpacu.

banyaknya indikator motivasi belajar siswa mencapai indikator keberhasilan dan hasil motivasi belajar $81,5 \%$. Pada siklus 2 menunjukkan bahwa $100 \%$ dari banyaknya indikator motivasi belajar siswa mencapai indikator keberhasilan dan hasil motivasi belajar $90,33 \%$.

\section{UCAPAN TERIMA KASIH}

Ucapan terimakasih ditujukan kepada Belmawa Ristekdikti dalam program Hibah PDSLPTK sebagai penyandang dana dalam proses penelitian ini. 


\section{DAFTAR PUSTAKA}

Fadillah, Ahmad. 2015. "Pengaruh Model Pembelajaran dan Kemampuan Komunikasi Matematika Terhadap Hasil Belajar Matematika Siswa". FIBONACCI: Jurnal Pendidikan Matematika dan Matematika. Vol. 1(2), pp: 1-12.

Fauziah, L.U., Hobri., dan Oktavianingtyas, E. 2016. "Penalaran Logis dalam Memecahkan Masalah Matematika Pokok Bahasan Aritmatika Sosial pada Siswa Kelas VII SMP Negeri 4 Jember”. Jurnal Edukasi. Vol. III (1), pp: 15-17.

Inda, D.H. 2017. "Keefektifan Model Aptitude Treatment Interaction dalam Meningkatkan Hasil Belajar dan Kepercayaan Diri”. Prosiding. Dalam: , Seminar Matematika dan Pendidikan Matematika UNY 2017, pp: PM751-PM758.

Putri, F.M. 2016. "Pengembangan Bahan Ajar Matematika Dasar Jurusan Non Eksak". FIBONACCI: Jurnal Pendidikan Matematika dan Matematika. Vol. 2(1), pp:44-52

Rosiyanti, Hastri. 2016. "Penggunaan Software LINDO dengan Metode Pembelajaran Penemuan Terbimbing untuk Meningkatkan Motivasi Belajar Mahasiswa Matematika Angkatan 2013 pada Mata Kuliah Program Linier". FIBONACCI: Jurnal Pendidikan Matematika dan Matematika. Vol. 2(2), pp: 19-27.

Sumar, W.T., 2016. Strategi Pembelajaran dalam Implementasi Kurikulum Berbasis Soft Skill. Yogyakarta: Deepublish. 